\title{
Powder for Solution for Skin-Prick Test Dosage Form
}

National Cancer Institute

\section{Source}

National Cancer Institute. Powder for Solution for Skin-Prick Test Dosage Form. NCI

Thesaurus. Code C149852.

Solid sterile preparation consisting of one or more powder intended to be dissolved in the specified liquid to obtain a solution for skin-prick test. 